\title{
Effect of Chronic Nicotine Administration on the Pro-oxidant Antioxidant Balance of Mice Serum: Role of Rosmarinic Acid
}

\author{
Naim Sharafi Ahvazi ${ }^{1}$, Erfan Daneshi ${ }^{2}$, Bahram nikkhoo ${ }^{3}$, Daem Roshani ${ }^{4}$, Mohammad Jafar Rezaei $^{5}$, \\ Hamid Reza Asgari ${ }^{6}$, Morteza Abouzaripour ${ }^{7}$ \\ 1. MSc. of Anatomy, Department of Anatomy, Faculty of Medicine, Kurdistan University of Medical Sciences, Sanandaj, \\ Iran. ORCID ID: 0000-0003-3468-5856 \\ 2. Assistant professor, Department of Anatomy, Faculty of Medicine, Kurdistan University of Medical Sciences, Sanandaj, \\ Iran. ORCID ID: 0000-0001-8265-2729 \\ 3. Associated professor, Department of Pathology, Faculty of Medicine, Kurdistan University of Medical Sciences, Sanandaj, \\ Iran. ORCID ID: 0000-0002-1833-4928 \\ 4. Associated professor, Social Determinants of Health Kurdistan Research Center, Kurdistan University of Medical \\ Sciences, Sanandaj, Iran. ORCID ID: 0000-0003-4746-1114 \\ 5. Associated professor, Department of Anatomy, Faculty of Medicine, Kurdistan University of Medical Sciences, Sanandaj, \\ Iran. ORCID ID: 0000-0003-5758-7889 \\ 6. Assistant professor, Department of Anatomy, Faculty of Medicine, Iran University of Medical Sciences, Tehran, Iran. \\ ORCID ID: 0000-0002-1864-0909 \\ 7. Assistant professor, Department of Anatomy, Faculty of Medicine, Kurdistan University of Medical Sciences, Sanandaj, \\ Iran., (Corresponding Author), Tel: 087-33664657, Email: Abouzary.M@muk.ac.ir, ORCID ID: 0000-0002-5073-4171
}

\begin{abstract}
Background and Aim: In this experimental study, nicotine has been recognized to result in oxidative stress by inducing the generation of reactive oxygen species. The current research was designed to investigate the protective effect of rosmarinic acid, a radical scavenger and antioxidant, on Pro oxidant anti-oxidant balance of serum in nicotine treated mice.

Materials and Methods: Thirty-six mature male NMRI mice were divided into 6groups: (two controls, two nicotine-treated $[0.5 \mathrm{mg} / \mathrm{kg}]$, and two nicotine plus rosmarinic acid [10 $\mathrm{mg} / \mathrm{kg}]$ ) were used in this study and treated for 15 and 30days respectively. The standard protocol was used to measure pro-oxidant-antioxidant balance, superoxide dismutase, and serum Catalase.

Results: As compared to control group $(90 \pm 3.03315 \mathrm{HK})$, the 15-day results, in nicotinetreated group $(100 \pm 5.17687 \mathrm{HK})$ there was a significant increase in the serum PAB ratio. Similarly, for samples of the day 30 , there was a significant increase in the serum PAB ratio of nicotine-treated group $(106 \pm 3.52136 \mathrm{HK})$ versus control group $(87 \pm 1.32916 \mathrm{HK})(\mathrm{P} \leq 0.05)$. SOD of $15(1.21 \pm 1.12)$ and 30 days $(1.89 \pm 0.26)$ treated groups, showed significant decreased versus control groups $(2.90 \pm 0.09),(2.82 \pm 0.08)$ respectively $(\mathrm{P} \leq 0.05)$.

Catalase of $15(12.13 \pm 2.30)$ and 30 days (11.57 \pm 1.42$)$ treated groups, showed significant decreased versus control groups $(25.12 \pm 2.21),(24.1 \pm 1.29)$ respectively $(\mathrm{P} \leq 0.05)$.

Conclusion: These results indicate that rosmarinic acid improves the level of antioxidant enzymes and modifies pro-oxidant-antioxidant imbalance
\end{abstract}

Keywords: Antioxidants, Rosmarinus, Nicotine, Serum

Received: June 20, $2019 \quad$ Accepted: Jan 19, 2020

How to cite the article: Naim Sharafi Ahvazi, Erfan Daneshi, Bahram nikkhoo, Daem Roshani, Mohammad Jafar Rezaei, Hamid Reza Asgari, Morteza Abouzaripour. Effect of chronic nicotine administration on the prooxidant antioxidant balance of mice serum: role of Rosmarinic acid. SJKU 2020; 25 (2): 54-60

Copyright (C) 2018 the Author (s). Published by Kurdistan University of Medical Sciences. This is an open access article distributed under the terms of the Creative Commons Attribution-Non Commercial License 4.0 (CCBYNC), where it is permissible to download, share, remix, transform, and buildup the work provided it is properly cited. The work cannot be used commercially without permission from the journal 


\section{بررسى اثر تجويز مز من نيكوتين بر روى تعادل اكسيدانى - آنتى اكسيدانى سرم موش: نقش}

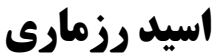

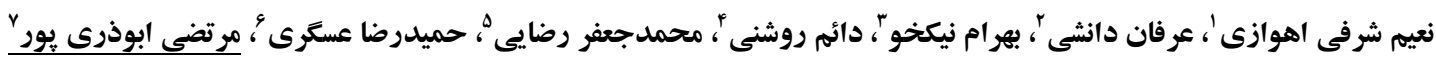

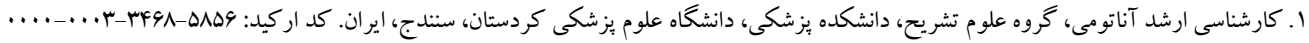

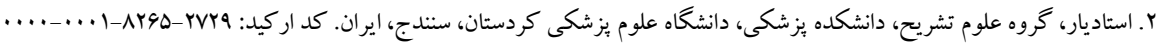

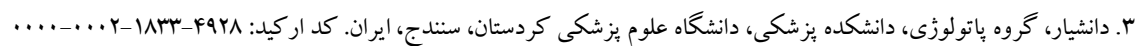

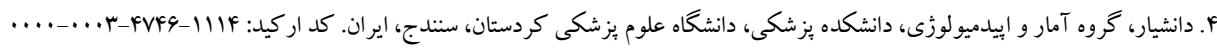

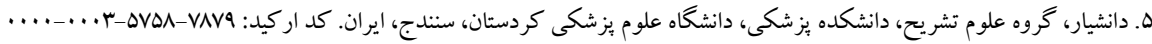

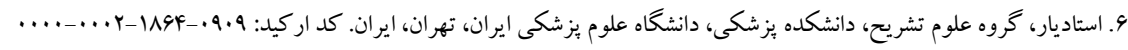

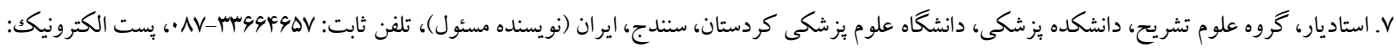
........r-ه.Vr-F|VI: Abouzary.M@muk.ac.ir

جִكيله

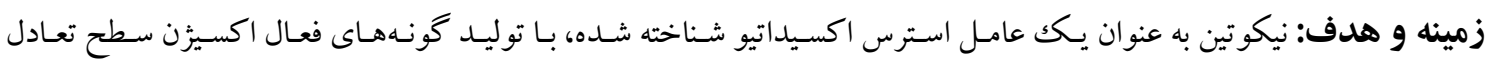

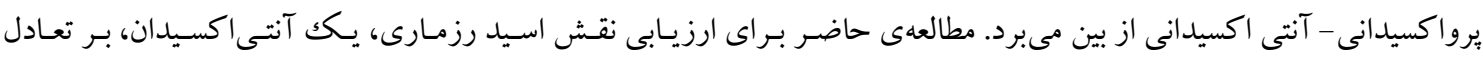

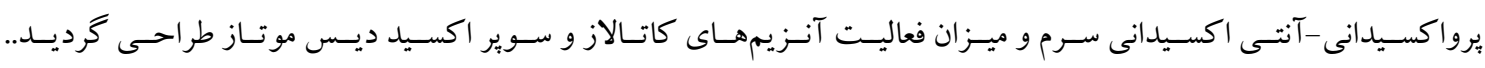

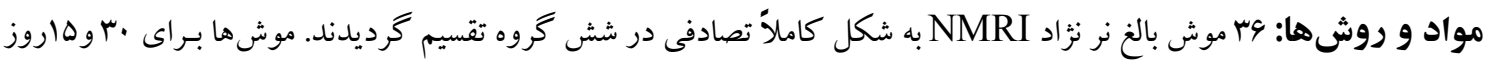

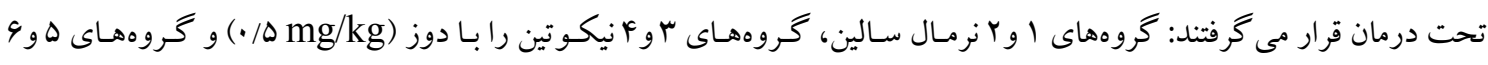

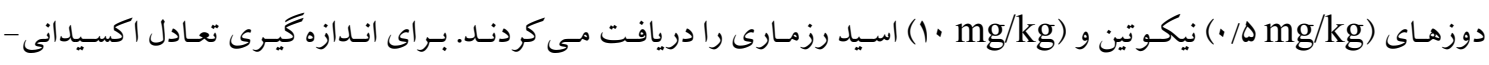

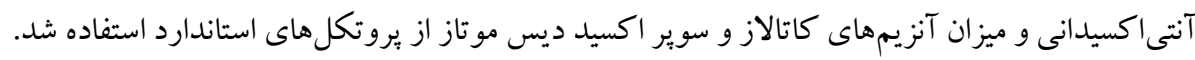

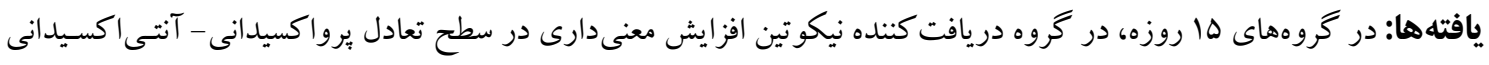

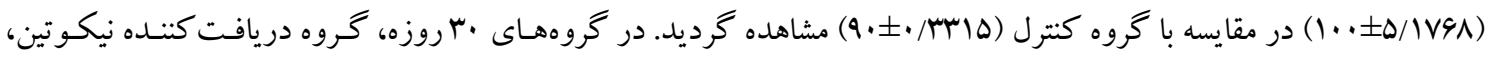

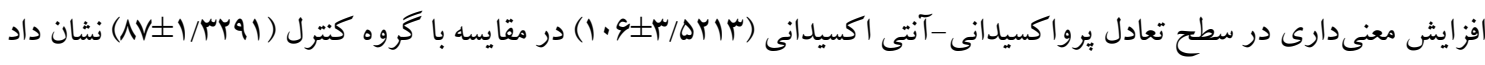

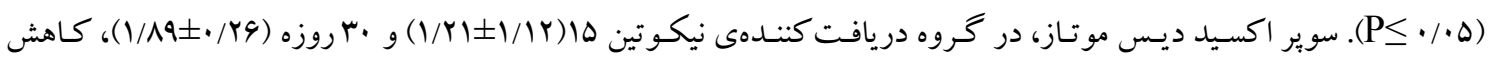

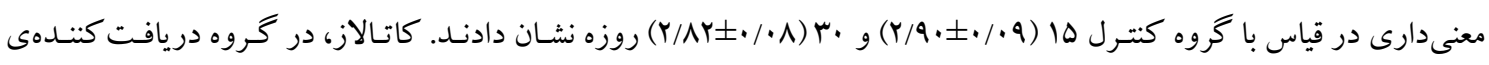

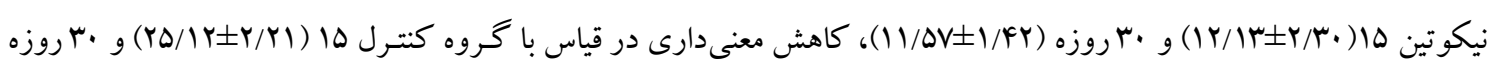

$$
\text { (PS }
$$

نتيجه كيرى: نتايج نشان مىدهد كه اسيد رزمارى موجب اصلاح سطح آنزيمهاى آنتىاكسيدانى شده و عدم تعادل يرواكسيدانى -

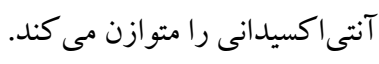

كلمات كليدى: آنتى اكسيدانها، رزمارينيك اسيد، نيكوتين، سئن سرم

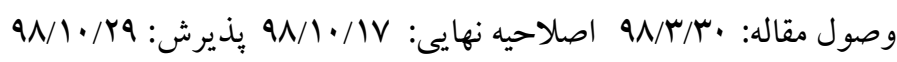


يكك تر كيب فنولى طبيعى است كه در گياهـان ردهى (RA لامياسيا (Lamiaceae) از جملهه نعنا، ريحـان و رزمـارى يافت مى گردد. ارزش دارويى اين ماده ، بخصوص در مورد نقش آنتى اكسيدانى آن به خوبى يذيرفته شده است (^و V).

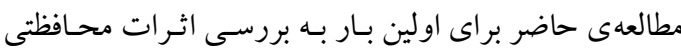

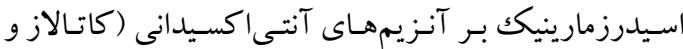

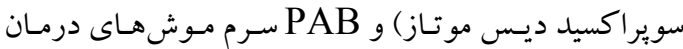
شده با نيكو تين طراحى گرديده است.

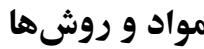
حيوانات و گروههاى مورد مطالعه: در اين مطالعهى تجربى،

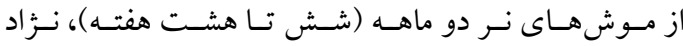

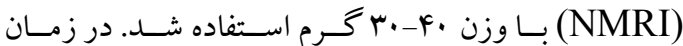
آزمايش، حيوانات در حيوانخانه گروه آناتومى دانشكده

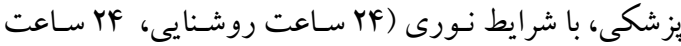
تاريكى) و حرارتى بهينه، در قفسهاى بِاستيكى و دسترسى لِّى

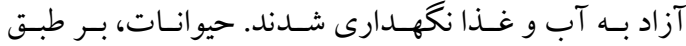
دستو رالعمل هاى دانشگاه علوم يز شكى كردستان نخهـدارى

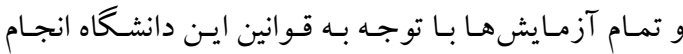
كرديد.4" عدد موش بهطور تصادفى در 4 گرروه كنترل و درمان توزيع شدند. از آنجايى كه تزريقات براى مدات زمان مان

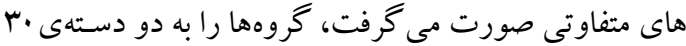
و ها روزه تقسيم نمـوديم: Y گـــروه كنتـرل (نرمـال سـالين

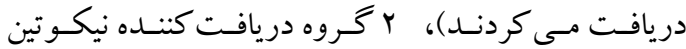

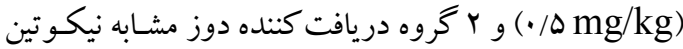

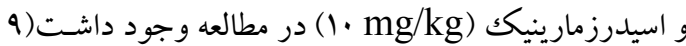

آمـادهسـازى نيكـوتين:هيـدروزن تارتـارات نيكـوتين 9ه٪ بـ شــماره (Nicotine hydrogen tartrate) was purchased from BDH ) rqlf. محصـول (Chemical Ltd, Poole, England

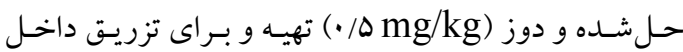
صفاقى مورد استفاده قرار گرفت (r و Y).
مقدمه از آنجايى كه نيكو تين به عنوان جايكزين ايمن ترى نسبت بـه

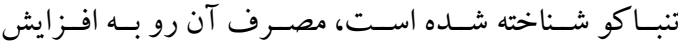

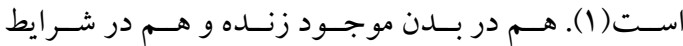
آزمايشگاه، نيكوتين موجب استرس اكسيداتيو مى گردد بـ (Y). در مورد مكانيسم اثر القاء استرس اكسيداتيو توسط نيكوتين،

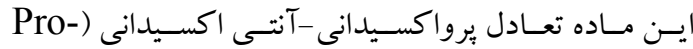
- oxidant Antioxidant Balance هاى موش صحر ايى افزايش داده(r) و نيز موجـب كاهش ميزان آنزيمهاى آنتى اكسيدانى :لاسـما در مـوش صـرايى ماده مى گردد( (F). در اين خصوص، محققين نشان دادند كه.

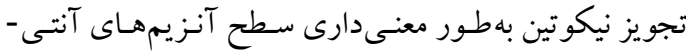

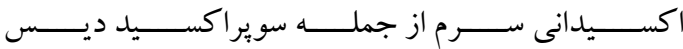
موتـاز(Superoxide Dismutase)(SOD) و كاتـالاز (Catalase) ديس موتـاز، آنزيمى اسـت كه بـاككسازى راديكالهـاى

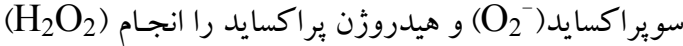
مى دهد. كاتالاز و سويراكسيد ديس موتاز بـا جلو گيرى از

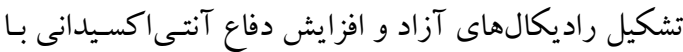
آسيب ايجاد شده مقابله مى كنند. استرس اكسيداتيو تعادل بين توليد گونههـاى فعـال اكسيزن (Reactive oxygen species)(ROS) را جهار نقصان كرده و در يـاتوزنز بيمـارىهـاى متنوعى از جملهـ ديابــ؛ سـرطان و بيمـارىهـاى قلبى عروقى سـهيم

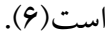
راديكــالهــاى آزاد ايجـاد شــهـ طـى اسـترس اكسـيداتيو مى توانند اثرات زيانبارى بـر اجزاء سـلول از جمله غشـاءها، لييويوتئين ها، كربو هيدراتها، دئو كسى ريبونو كلئيك اسـيد و ويبونو كلئيك اسيد (DNA) براى اصلاح سطوح بـالاى PAB بـه عنوان يكك شـاخص

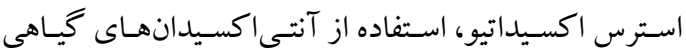

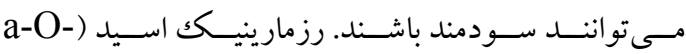
caffeoyl-3, 4-dihydroxyphenyllactic acid; 
توسط متـد ارائه شـده توسط ابـ (Aebi) در سـال $19 \wedge \uparrow$

اندازه گيرى گرديد. اندازه گيرى توسط ميزان تجزيه

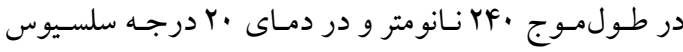
انجام گرديـــ. فعاليت آنزيم از طريق ميزان جـذب نـورى

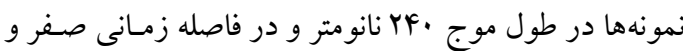
ها ثانيه محاسبه و فعاليـت آنزيم از طريق فرمـول مربوطه

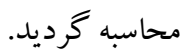

One-way تجزيه و تحليل آمارى: دادهها با روش آمـارى ANOVA with a post-hoc Tukey

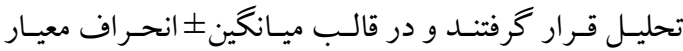
PAB نمايش داده شدند. تفـاوت مقـادير (mean \pm SD) با هـ/ براى معنى دارى يا عدم آن مورد محاسبه واقع

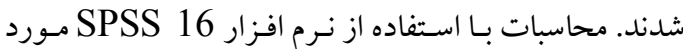
بررسى قرار گرفتند(ه).

يافتهها

دادههـاى كمـى ميـزان PAB سـرم مـوشهـا، در نمـودار 1 خلاصه شدهاند. براى راحتى بيشتر نتايج روزهـاى ها و ·rرا

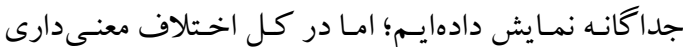

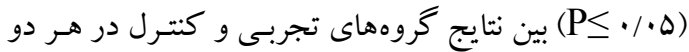

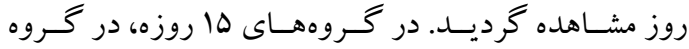
دريافت كننده نيكوتين افزايش معنى دارى در سطح تعادل

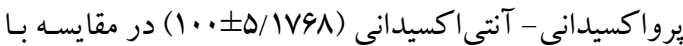

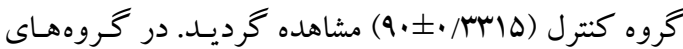

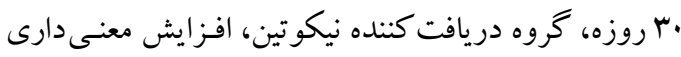

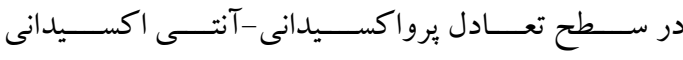

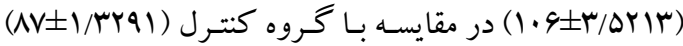

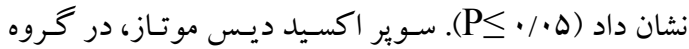

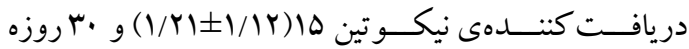

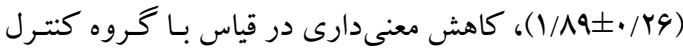

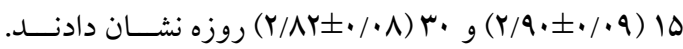

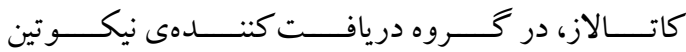

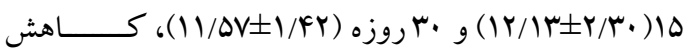

جمع آورى نمونه خـون: خون هـر حيوان از طريق سينوس

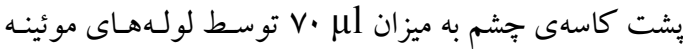
هيارينـه گرفتـه و در لولـهى آزمـايش ســاده ريختـه شــــ. نمونههاى هموليز شده از مطالعه خارج مى شــدند. جداسـازى سرم از خون نمونهها توسط سـانتريفيوز ها دقيقهاى بـا دور إ..... اصورت كرفت.

اندازه گيرى تعادل اكسيدانى-آنتىاكيدانى سرم موش خرف طبق يروتكل استاندارد( •1) محلولها ساخته و بـا استفاده از كيت الايزا و دستخاه خواننده الايززا، ميزان PAB سنجيده شد. بـهطور خلاصهه و اخر بخواهيم فقط در مـورد نكـات تخصصى اين يروتكل اشارهاى كرده باشيم، يس از به دست

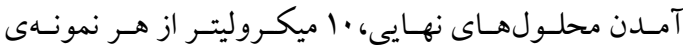

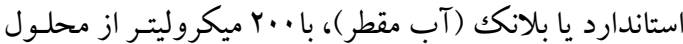
كـارى تركيب و بـه درون كيـت 99 جـاهكى الايـزا ريختهـ

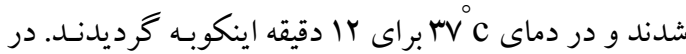
انتهاى اين زمان، وانش رنكى (Colorimetric) با افزودن

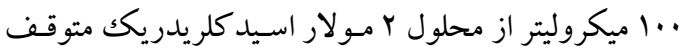

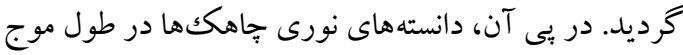

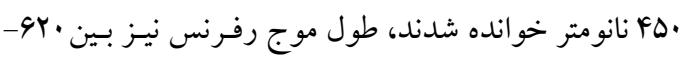

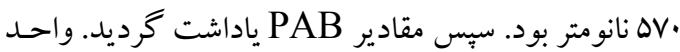

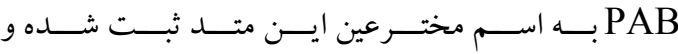
HK(Hamidi and Koliakos) ســنش سـوير اكســيد ديسس موتساز و كاتـالاز: ميـزان

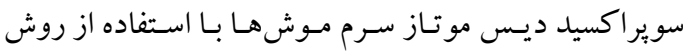

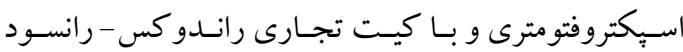

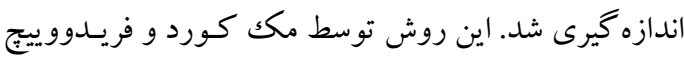

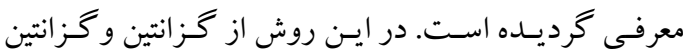
اكسايد براى توليد راديكـالهـاى سويراكسيد استفاده مسى -

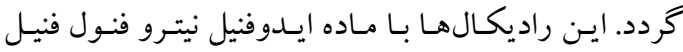
تترازوليوم كلرايد (I.N.T) واكنش داده و يكك رنگك قرمز

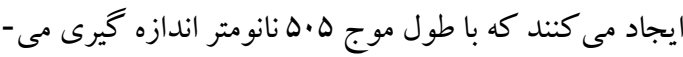
كردد. فعاليت آنزيم سوير اكسيد ديس موتـاز بـا ميزان مهار اين واكنش اندازه گيرى مى گردد (ه). سنجش آنزيم كاتلالاز 


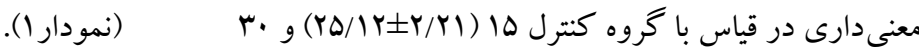

$$
\begin{aligned}
& \text { روزه (P (Y }
\end{aligned}
$$

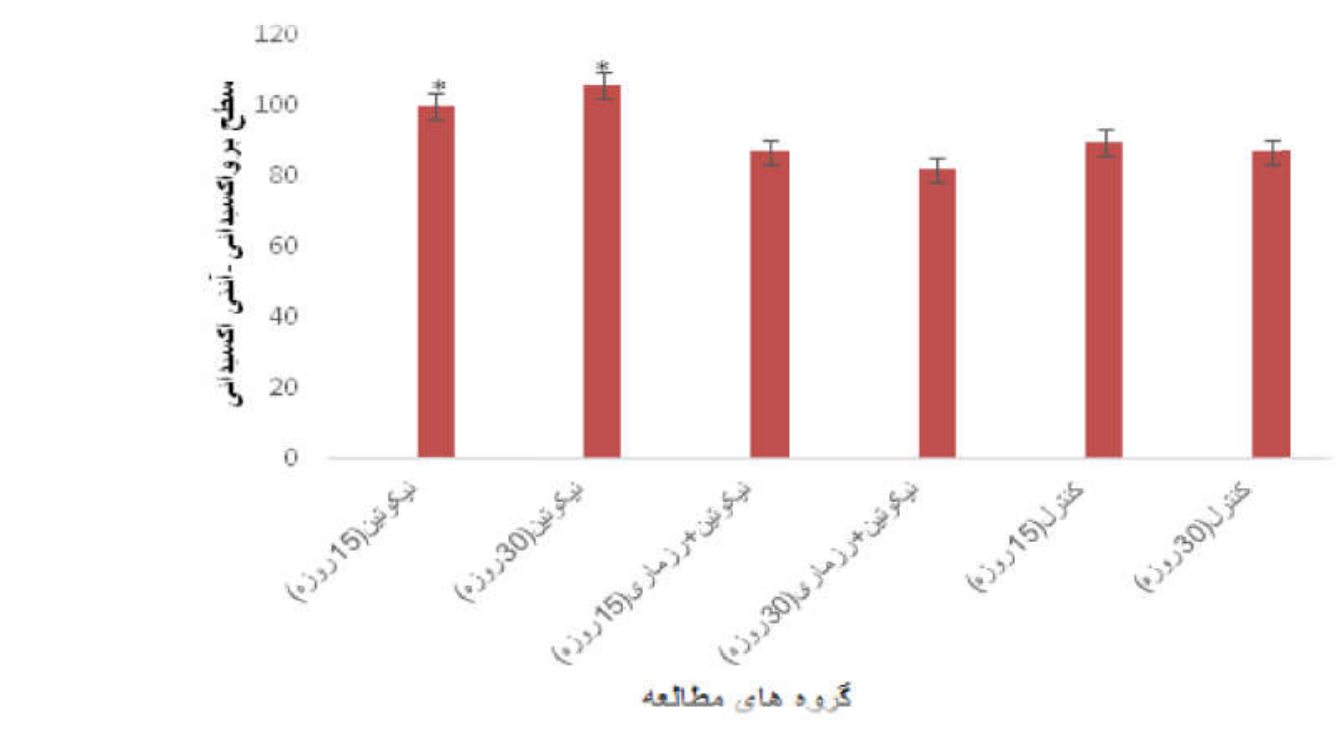

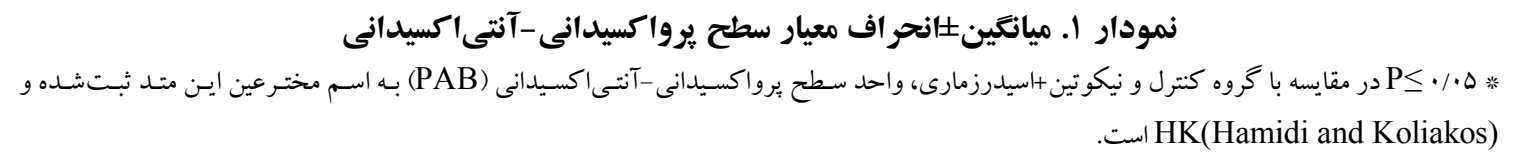

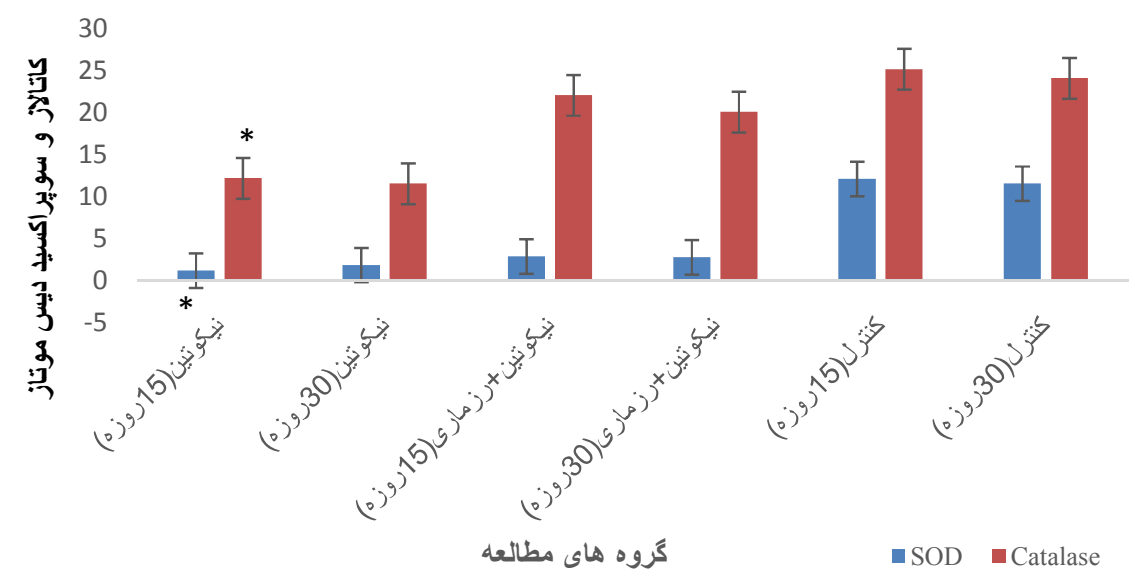

نمودار r. ميانكيندانحر اف معيار كاتالاز و سوير اكسيد ديس موتاز

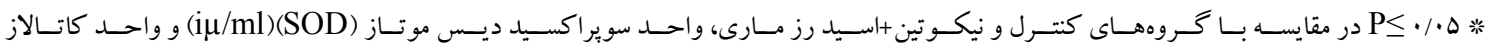
است. ( $(\mu \mathrm{mol} / \mathrm{L})($ Catalase $)$ 
الكـــى مشـابهى بـا تر كيبـات فنـولى دارد و اثـرات آنتى -

اكسيدانى آنها مربوط به حضور تر كيباتى جـون كارنوسول

(Carnosol)

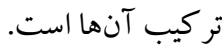

Galic ( در اين مورد، معلوم شده است كه كاليكك اسيد

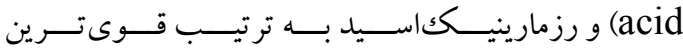
آنتسى اكسـيدانهــا در ميـان اسـيدهاى ســاده فنوليـك و وركي هيدروكسـيل ســيناميك (Hydroxyl cinnamic) هستـند(1). كَزارش شـده اسـت كـه اسـيدرزمارى بـا دوز

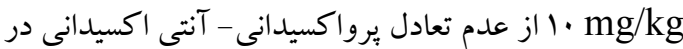
كبد موشهاى صحرايى تحت تأثير اتانل جلو گيرى كرده اسـت(9). فعاليـت آنتى اكسيدانى فنسول معمـولاً بـهـ خـروه هيدرو كسيل مربوط مسشـود؛ امـا تنها عامـل تعيين كنتـده تو انايى فعاليتهاى آنها نيست(1ه). ظرفيت مهار راديكال

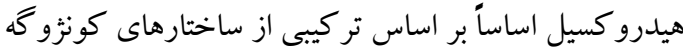

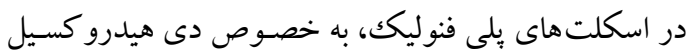
فنـول يـا كـاتكول (Catechol) و نيـز حضـور گحروههـاى

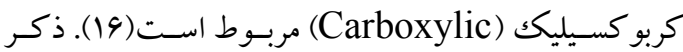
شده است كه دو ساختار كاتكول كونزو كه با كربو كسيليك اسـيد در رزمـارى، فعاليــت آنتـى اكسـيدانى را افـزايش مى دهند(IV) و هم جنين حضور كروه كـاتكول در حلقهى آروماتيك (C11-C12) اسكلت فنولى رزمارى، احتمالاً

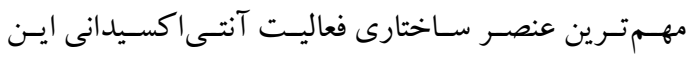
تركيبات است. در مطالعهى حاضر، درمان موشهاى مواجـه

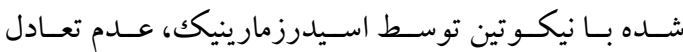

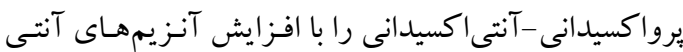
اكسيداتيو كاتالاز و سوير اكسيد ديس موتاز بهبود بخشيد.

\section{نتيجه كيرى}

رتينويكك اسيد احتمالاً يك داروى ارزشمند براى محافظت از اثرات استرس اكسيداتيو نيكوتين بوده و مىتواند موجب تعادل آنزيمهاى آنتى اكسيدانى در خون گرددد.
نتايج مطالعهى حاضر نشان داد كه تجويز دوز مزمن نيكوتين موجـب عـدم تعـادل سططح برواكسيدانى -آنتى اكسيدانى

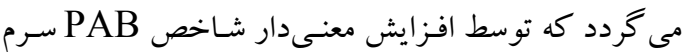
نمود بيدا مى كند ، اخرجه سطح PAB در گروه مواجه شده با اسيدرزمارينيك و نيكوتين، به ميزان نرمال نزديكك گثتـه

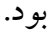

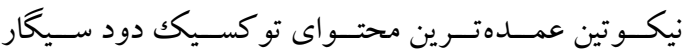

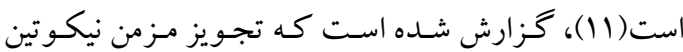
موجب ايجاد راديكالهاى آزاد در بافتهاى موش صحرايى

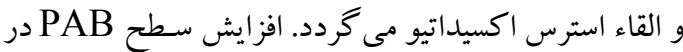
اين موشها مىتواند به علت نقش مهارى نيكوتين بـر روى آنزيمهاى آنتى اكسيدانى در سرم موش باشد(ه)، كه توجيهكنندهى علت نتايج مطالعهى ما نيز است.

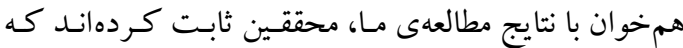

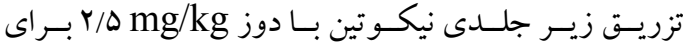
مــد r هفتـه، موجـب كــاهش معنسى دار آنـزيمهــاى سوير اكسيد ديس موتـاز، كاتـالاز و كلو تـاتيون يراكسيداز

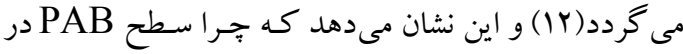
موش هاى مواجـه شــده بـا نيكـوتين افزايش يافته اسـت. در خصوص مكانيسم احتمالى نيكوتين در بـر هـم زدن تعـادل

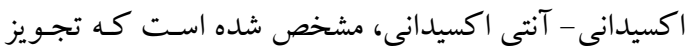
اين ماده، استرس اكسيداتيو را القـاء كرده اسـت، نيكوتين

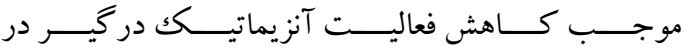
دتو كسيفيكاسيون تواند علت بروز نتايج مطالعهى ما را توجيه كند.

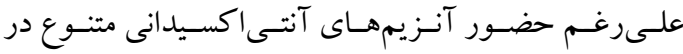
بافـتهـاى بـدن موجـود زنــه، تجـويز آنتـى اكسيدانهـاى اكـزوزن بـراى كـاهش اثـرات گونـهــاى فعـال اكسيزّن و استرس اكسيداتيو، از اهميت بالايى برخوردار است.

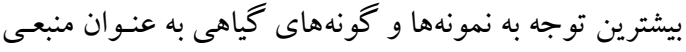
براى آنتى اكسيدانها، به اسيدرزمارى صورت گرفتهه است. در مطالعات ييشين (rا) نشـان داده شـده اسـت كـه رزمـارى 


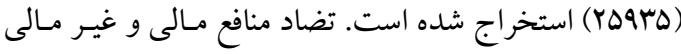

$$
\begin{aligned}
& \text { در خصوص اين برُوهش براى نويسنگان مقاله وجود ندارد. }
\end{aligned}
$$

$$
\begin{aligned}
& \text { تشكر و قدردانى }
\end{aligned}
$$

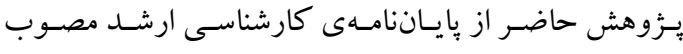

$$
\begin{aligned}
& \text { دانشكده يزشكى دانشكاه علوم يزشكى كردستان با كد لئر }
\end{aligned}
$$

1. Chaturvedi P, Mishra A, Datta S, Sinukumar S, Joshi P, Garg A. Harmful effects of nicotine. Indian J Med Paediatr Oncol. 2015: 36(1):24.

2. El-Sokkary GH, Cuzzocrea S, Reiter RJ. Effect of chronic nicotine administration on the rat lung and liver: beneficial role of melatonin. Toxicology. 2007: 239(1-2):60-7.

3. Das S, Chakraborty SP, Roy S, Roy S. Nicotine induced pro-oxidant and antioxidant imbalance in rat lymphocytes: in vivo dose and time dependent approaches. Toxicol Mech Methods. 2012: 22(9):711-20.

4. Chattopadhyay K, Chattopadhyay BD. Effect of nicotine on lipid profile, peroxidation \& antioxidant enzymes in female rats with restricted dietary protein. Indian J Med Res. 2008: 127(6).

5. Oyeyipo IP, Raji Y, Bolarinwa AF. Nicotine alters serum antioxidant profile in male albino rats. $\mathrm{N}$ Am J Med Sci. 2014: 6(4); 168.

6. Vendemiale G, Grattagliano I, Altomare E. An update on the role of free radicals and antioxidant defense in human disease. Int J Clin Lab Res. 1999: 29(2):49.

7. De Oliveira NC, Sarmento MS, Nunes EA, Porto CM, Rosa DP, Bona SR, et al. Rosmarinic acid as a protective agent against genotoxicity of ethanol in mice. Food Chem Toxicol .2012: 50(5):1208-14.

8. Alamed J, Chaiyasit W, McClements DJ, Decker EA. Relationships between free radical scavenging and antioxidant activity in foods. J Agric Food Chem. 2009: 57(7):2969-76.

9. Hasanein P, Seifi R. Beneficial effects of rosmarinic acid against alcohol-induced hepatotoxicity in rats. Can J Physiol Pharmacol. 2018: 96(1):32-7.

10. Alamdari DH, Paletas K, Pegiou T, Sarigianni M, Befani C, Koliakos G. A novel assay for the evaluation of the prooxidant-antioxidant balance, before and after antioxidant vitamin administration in type II diabetes patients. Clin Biochem. 2007: 40(3-4):248-54.

11. Hoffmann D, Rivenson A, Hecht SS. The biological significance of tobacco-specific Nnitrosamines: smoking and adenocarcinoma of the lung. Crit Rev Toxicol. 1996: 26(2):199-211.

12. Muthukumaran S, Sudheer AR, Menon VP, Nalini N. Protective effect of quercetin on nicotineinduced prooxidant and antioxidant imbalance and DNA damage in Wistar rats. Toxicology. 2008: 243(1-2):207-15.

13. Thorsen MA, Hildebrandt KS. Quantitative determination of phenolic diterpenes in rosemary extracts: aspects of accurate quantification. J Chromatogr A. 2003: 995(1-2):119-25.

14. Soobrattee MA, Neergheen VS, Luximon-Ramma A, Aruoma OI, Bahorun T. Phenolics as potential antioxidant therapeutic agents: mechanism and actions.Mutat Res. 2005: 579(1-2):200-13.

15. Bendary E, Francis RR, Ali HM, Sarwat MI, El Hady S. Antioxidant and structure-activity relationships (SARs) of some phenolic and anilines compounds. Annals of Agricultural Sciences. 2013: 58(2):173-81.

16. Benavente-García O, Castillo J, Marin FR, Ortuño A, Del Río JA. Uses and properties of citrus flavonoids. J Agric Food Chem. 1997: 45(12):4505-15.

17. Del Bano MJ, Castillo J, Benavente-García O, Lorente J, Martín-Gil R, Acevedo C, et al. Radioprotective- Antimutagenic Effects of Rosemary Phenolics against Chromosomal Damage Induced in Human Lymphocytes by $\gamma$-rays. J Agric Food Chem. 2006: 54(6):2064-8. 